\title{
Cikkismertetés: Népegészségügy 3.0
}

\author{
Article review: Public Health 3.0
}

Ismertető: $\quad$ Vitrai József $\square$

Nemzeti Népegészségügyi Központ

Ismertetett cikk: DeSalvo KB, Wang YC, Harris A, et al. Public Health 3.0: A Call to Action for Public Health to Meet the Challenges of the 21st Century. Prev Chronic Dis 2017;14:170017. doi: $\underline{10.5888 / p c d 14.170017^{i}}$

Beküldve: $\quad$ 2019. 07. 28.

doi: $\quad$ 10.24365/ef.v60i4.500

Kulcsszavak: népegészségügy

Keywords: public health

\section{BEVEZETÉS}

Az Amerikai Egyesült Államok (USA) lakosságának egészségi állapotában elért igen jelentős fejlődés ellenére az egészségügynek komoly kihívásokkal kell szembenéznie: megtorpant a születéskor várható élettartam növekedése, nem csökkennek a társadalmi csoportok egészségi állapotában kimutatható különbségek. Kutatások igazolták, hogy az irányítószám erősebb egészségmeghatározó lehet, mint az öröklött tulajdonságok. ${ }^{1}$

\section{EGÉSZSÉGET BEFOLYÁSOLÓ LEGFONTOSABB TÁRSADALMI TÉNYEZŐ}

Ahhoz, hogy az egészségügy eredményesen javíthassa a lakosság egészségi állapotát, egy sor egészséget befolyásoló tényezőt kell kezelnie. Ilyenek például az oktatás, az egészséges és biztonságos környezet, a lakhatás, a közlekedés, a gazdaság és az egészséges élelmiszerekhez való hozzáférés. Mindezt figyelembe véve készítette el az USA Népegészségügyi Központja (Centers for
Disease Control and Prevention, $C D C$ ) a megelőzés „3 vödör" modelljét. A modell első eleme a hagyományos orvosi megelőzés, második az orvosi ellátáson kívüli megelőzés, míg a harmadik a populációs vagy közösségi szintű megelőzés. Minden területen szükséges fejlesztés, azonban a Népegészségügy 3.0 az utolsóra fókuszál. [1. ábra]

Az egészségügyi ellátórendszeren kívüli megelőzési tevékenységek, azaz a 2. és 3. „vödör” az egészséget befolyásoló társadalmi tényezők (az a társadalmi, fizikai és gazdasági környezet, amiben az emberek élnek és dolgoznak; angolul összefoglalóan „upstream”) közösségi szinten történő, igazoltan 5 éven belüli költséghatékonyságátii mutatja be a 2. ábra.

\section{A NÉPEGÉSZSÉGÜGY FEJLŐDÉSE}

Az USA népegészségügyének fejlődését a CDC három szakaszra osztja. Az első szakasz a késői XIX. és a XX. század elejére terjedt ki, tevékenységeit a korszerü biomedikális szemlélet határozta meg.

' Egy azonos címú, de kissé részletesebb, ún. fehér könyv elérhető itt: https://www.healthypeople.gov/sites/default/files/Public-Health-3.0-White-Paper.pdf

ii Az 5 éven belül egészségnyereséget biztosító beavatkozások részletesen itt érhetők el: https://www.cdc.gov/policy/hst/hi5/interventions/index.html 
A beavatkozások főképp a szanitációra, az ivóvízre és az élelmiszerbiztonságra, a védőoltásokra és az antibiotikumokra irányultak. A második szakasz a XX. század második felétől számítható, és a kapacitások rendszerszintű megerősítése, a professzionalizáció, valamint a hagyományos népegészségügyi programokra fókuszálás jellemezte.

\section{Hagyományos orvosi megelőzés}

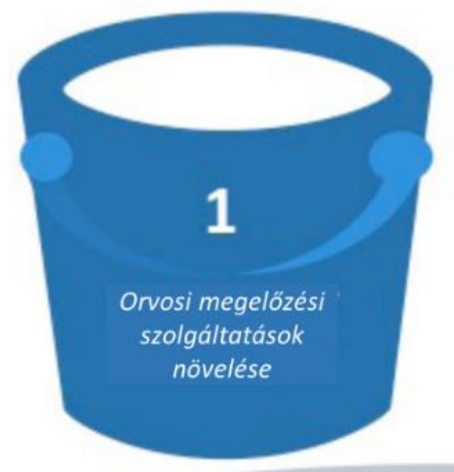

Orvosi ellátás

\section{Újszerü orvosi} megelőzés

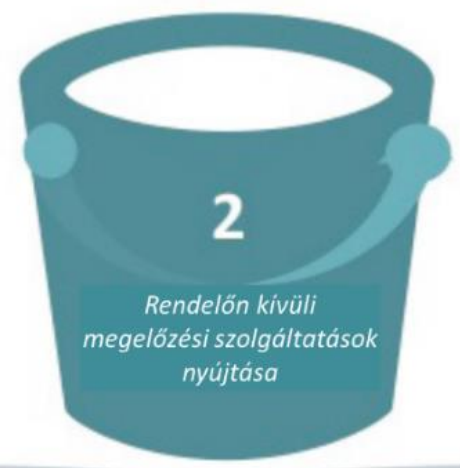

Népegészségügy

\section{Közösségi szintű megelőzés}

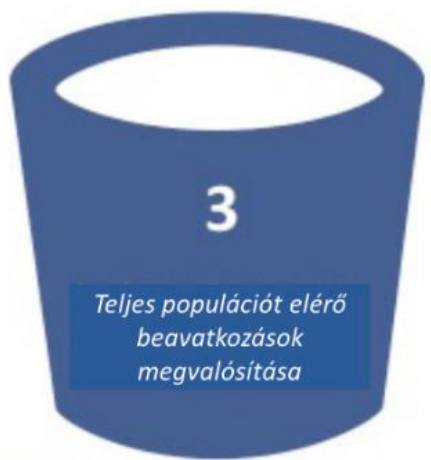

ljes populációt elér

beavatkozások

Forrás: az eredeti ábra magyar változata

\section{2. ábra: Öt éven belül egészségnyereséggel járó hatékony népegészségügyi beavatkozások}

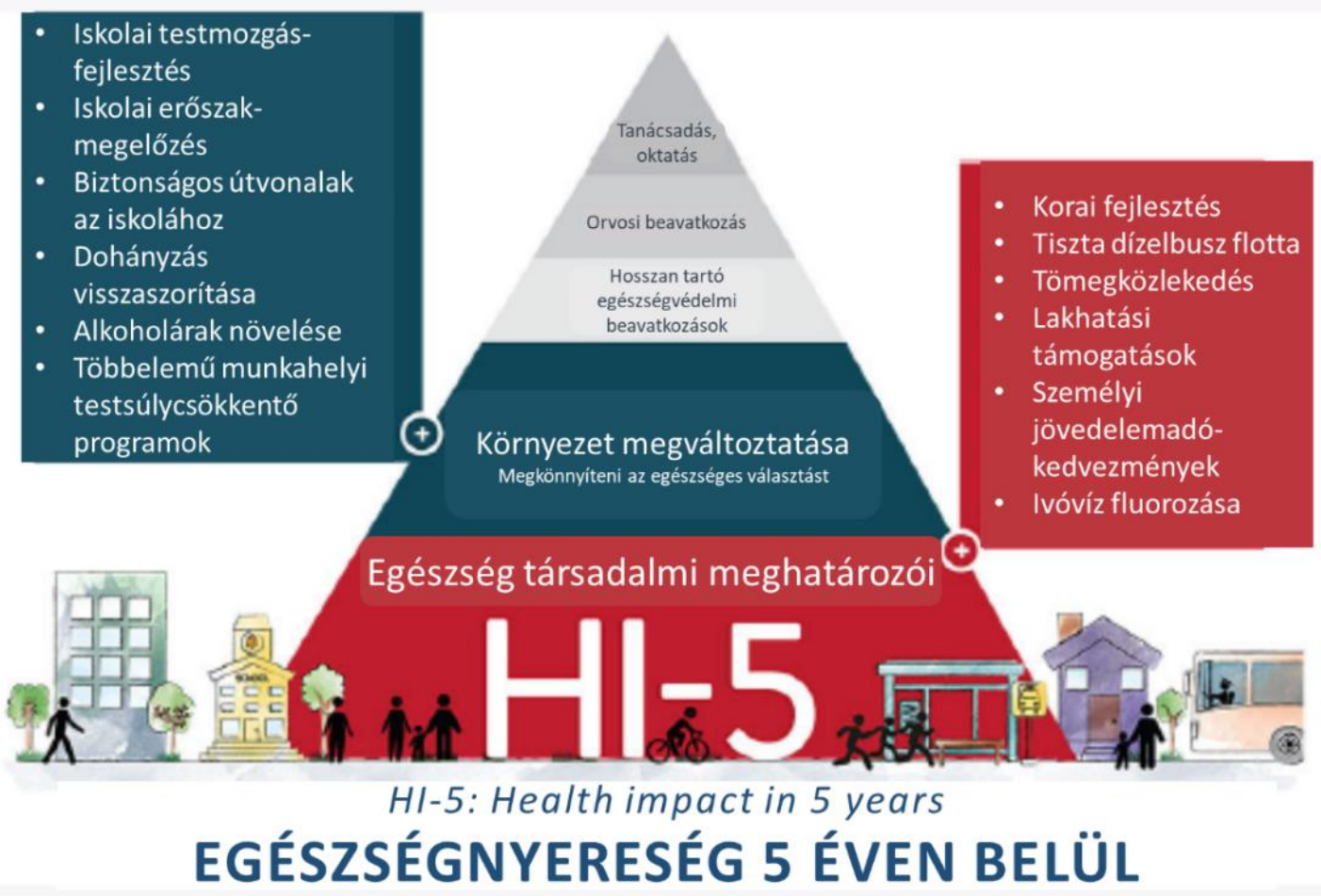

Forrás: az eredeti ábra magyar változata 


\section{NÉPEGÉSZSÉGÜGY 3.0: A NÉPEGÉSZSÉGÜGY MEGÚJULÁSA}

A Népegészségügy 3.0 elnevezés az új, harmadik szakaszra utal, és a hagyományos funkciók, valamint a programokon túlmutató, összehangolt ágazatközi együttmúködésen alapuló, a társadalmi-gazdasági környezetre irányuló népegészségügyi gyakorlatot jelzi. A főszerep ebben a kezdeményezésben a megújuló helyi népegészségügyi szervezeteknek jut, amik a korábbi sikeres tevékenységeik mellé programjukban felveszik az egészség társadalmi meghatározóira irányuló beavatkozásokat is. A kollektív cselekvést előmozdító helyi népegészségügyi vezetőnek a „Vezető Egészségstratéga” (Chief Health Strategist) szerepét kell felvállalnia, hogy mozgósítani tudja a közösséget az infrastruktúra megerősítéséhez és a szektorokon, hatáskörökön átnyúló, stratégiai partnerség kialakításához. Számos "úttörő" népegészségügyi szervezett elindult már ezen az úton, de a Népegészségügy 3.0 megvalósítását szolgáló átfogó elméleti keretrendszer, módszertan és eszköztár nem jött létre. Ezért 2016 során az USA Egészségügyi Minisztériuma országszerte fórumokat tartott különböző szektorok, érdekképviseleti szervezetek, helyi vezetők és az "úttörő" népegészségügyi szervezetek bevonásával az új kezdeményezés ismertetésére és a részvevők azzal kapcsolatos véleményeinek illetve tapasztalatainak összegyűjtésére.

\section{A NÉPEGÉSZSÉGÜGY 3.0 KULCSELEMEIiii}

A fórumok részvevőinek észrevételeit figyelembe véve a szerzők a Népegészségügy 3.0 megvalósitásához öt kulcselemet fogalmaztak meg. [3. ábra]

1. Erős vezetés és munkaerő: Nem csak több szakterületen felkészült, szakpolitikát értő munkaerő szükséges, hanem koalíciót építeni, adatokat és bizonyítékokat hasznosítani, valamint a "Vezető Egészségstratéga" szerep sikeres eljátszására képes vezetőkre is. A fórumok részvevői speciális képzések és továbbképzések bevezetését javasolták a Népegészségügy 3.0-t megvalósítani képes vezetők és a munkaerő számára.
2. Megerősített helyi szervezet: A Népegészségügy 3.0-t megvalósító szervezetet fel kell készíteni a közösségi partnerekkel való együttmúködésre. Ehhez a társadalmi-gazdasági környezetet megváltoztatására és az egészségegyenlőtlenségek csökkentésére felkészített szakemberek munkájához szükséges szervezeti felépítést, működésmódot, infrastruktúrát és eszközparkot szükséges kialakítani. A szervezetek Népegészségügy 3.0-ra való alkalmasságát a Népegészségügyi Akkreditációs Bizottság ellenőrzi. Az akkreditált szervezetek előnyt élveznek a különféle szövetségi támogatások elnyerésében.

3. Stratégiai partnerség: A Népegészségügy 3.0 sikerének kulcsa az együttműködésre alapozott közös finanszírozású, irányítású és összehangolt cselekvés. A helyi érdekhordozók meggyőzéséhez és bevonásához megfelelő stratégia, az érintettekről információ, továbbá eltökéltség és jó kommunikációs képességek szükségesek. A helyi népegészségügyi szervezetnek felkészültnek kell lennie: olyan innovatív és fenntartható együttmúködést kell az érdekhordozókkal kialakítania, melynek jövőt illető elképzelései egyetértésen alapulnak, és alkalmas különféle források bevonására, kombinálására. [4. ábra]

4. Adatgyűjtés, -elemzés, -értékelés: A Népegészségügy 3.0 hatékony megvalósításához aktuális, megyei szint alatti részletezettségú, beavatkozások megvalósulására és eredményességére vonatkozó adatok gyűjtése és elemzése szükséges. A nyilvánossá tett, de anonimizált adatoknak le kell fedniük az orvosi ellátást, a népegészségügyi szolgáltatásokat, az egészség társadalmi meghatározóit, a lakó- és munkahelyi környezeti változásokat, valamint az egyenlőtlenségeket is.

5. Rugalmas és fenntartható finanszírozás: A Népegészségügy 3.0 megvalósításához nélkülözhetetlen a népegészségügy finanszírozási modelljének megújítása. Mivel a megelőzés csökkenti az orvosi költségeket, célszerú lenne az egészségügyi források egy részét a megelőzés eredményességével arányosan

\footnotetext{
iii Ez a rész az azonos címet viselő fehér könyv alapján készült
} 
átcsoportosítani a népegészségügy számára. Alternatív, nem állami források felkutatása és bevonása ugyancsak nélkülözhetetlen. Meg kell találni azokat a potenciális finanszírozókat, akik hajlandók a közösség javára áldozni, vagy akiknek törekvései a közösségi érdekekkel összhangba hozhatók.

\section{Népegészségügy 3.0}

\section{Kulcselemek}

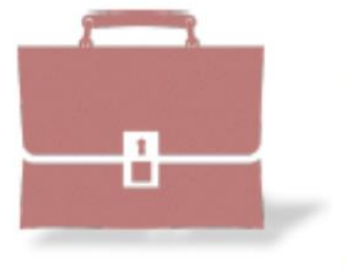

ERŐS VEZETÉS ÉS MUNKAERŐ
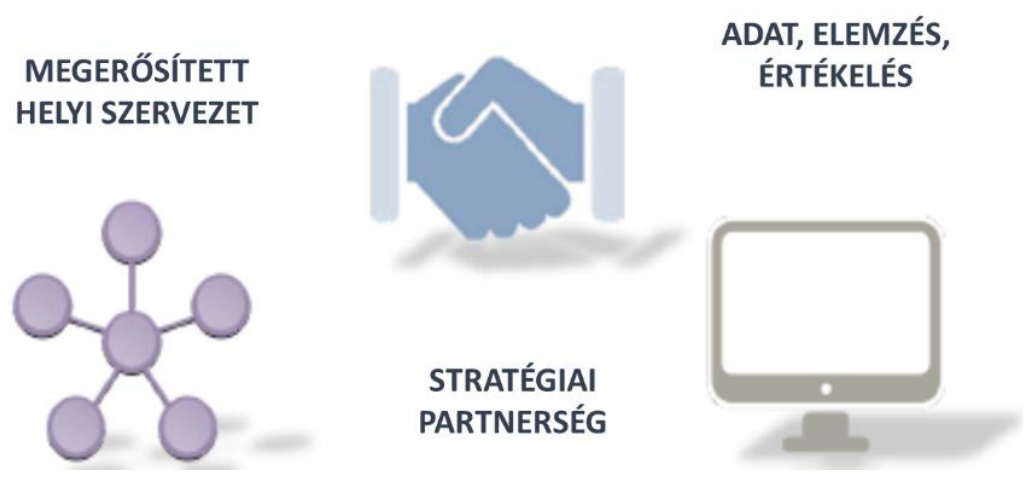

Forrás: az eredeti ábra magyar változata

\section{AJÁNLÁSOK A NÉPEGÉSZSÉGÜGY 3.0 MEGVALÓSÍTÁSÁHOZ}

Az országos fórumok, valamint az „úttörő” szervezetek tapasztalatai alapján a szerzők öt olyan ajánlást fogalmaztak meg, amelyek a népegészségügyi rendszernek a Népegészségügy 3.0-vá való átalakításához szükségesek:

1. A népegészségügyi vezetőknek fel kell vállalniuk a "Vezető Egészségstratéga” szerepet közösségük érdekében - együttmúködve minden partnerrel, hogy megvalósíthassanak az egészség társadalmi meghatározóira irányuló beavatkozásokat. A Népegészségügy 3.0specifikus képzéseket elérhetővé kell tenni a népegészségügyi szakemberek, illetve a hallgatók számára. Képessé kell tenni őket arra, hogy stratégiai partnerség építsenek ki, hasznosítsák az új típusú adatokat és alkalmazzák a rendszerszemléletet munkájukban.

2. A népegészségügyi szervezeteknek be kell vonniuk a közösségi érdekhordozókat mind a köz-, mind a magánszférából, hogy aktív, strukturált ágazatközi partnerségben, közös finanszírozással, szolgáltatással és irányítással Népegészségügy 3.0 stílusú kezdeményezéseket valósítsanak meg az egészséges, egyenlő és támogató közösségért.

3. Törekedni kell arra, hogy valamennyi népegészségügyi szervezet megfeleljen a Népegészségügyi Akkreditációs Bizottság kritériumainak azért, hogy valamennyi amerikai állampolgárt akkreditált szervezetek szolgáljanak. E mellett folyamatosan értékelni kell működésük egészséghatását, az akkreditációhoz szükséges fejlesztések költségeinek megtérülését.

4. Aktuális, megbízható, megyei szint alatti részletezettségú és a beavatkozások tervezéséhez, értékeléséhez hasznosítható adatok, továbbá egyszerú indikátorok közreadása szükséges a megelőzés sikerességének értékeléséhez. Olyan indikátorkészlet kialakítása és alkalmazása szükséges, amely a személyes adatok védelmének biztosítása mellett információt 
szolgáltat az orvosi ellátásról, a népegészségügyi szolgáltatásokról, különösen az egészség társadalmi meghatározóiról, a lakó- és munkahelyi környezet változásairól, valamint az egyenlőtlenségekről.

5. Javítani és alapvetően változtatni kell a népegészségügy finanszírozását, újszerű támogatási modell kidolgozása szükséges a Népegészségügy 3.0 stílusú irányítás és a megelőzés érdekében. Bátorítani kell a többféle forrásból kombinált, újrabefektetetéssel megnövelt finanszírozási megoldásokat, amelyeket mind az infrastruktúra fejlesztésére, mind a terepmunka javítására fordítanak. Nélkülözhetetlen továbbá, hogy a népegészségügyi szervezetek maguk számára meghatározzák, mekkora forrás szükséges a minimális kapacitások biztosításához és szolgáltatások nyújtásához.

\section{A NÉPEGÉSZSÉGÜGY 3.0 MEGVALÓSÍTÁSÁNAK AKADÁLYAI}

Sok közösség számára a Népegészségügy 3.0 megvalósítása nehézségekbe ütközik majd az elérhető központi források szűkössé válása miatt. További problémát jelent a szükséges adatok és információk hiánya, a napi kötelezettségek ellátása, a tapasztalatok és készségek hiánya, mely akadályozza a legtöbb népegészségügyi szakembert abban, hogy „Vezető Egészségstratéga”-ként a különböző ágazatokat együttműködésre bírja. Végül, a helyi szervezetek infrastruktúrája sokszor elégtelen az eredményes és költséghatékony beavatkozásokhoz.

\section{KÖVETKEZTETÉSEK}

A Népegészségügy 3.0 a helyi népegészségügyi szervezetek megerősödéséhez vezető izgalmas és innovatív időszak, amelyben a „Vezető Egészségstratéga" irányításával a különféle szektorok bevonásával az egészség társadalmi meghatározóira irányuló beavatkozások valósulnak majd meg. Az egyenlőségre és a társadalmi meghatározókra figyelemmel minden egyén és szervezet közös felelősséget vállalva-fajra, etnikumra, nemre, szexuális orientációra, földrajzi és jövedelemre tekintett nélkül-biztosítja az egészséges élet feltételeit. A Népegészségügy 3.0 intézményesítése országszerte valamennyi közösség számára megteremti ezt a lehetőséget.

\section{4. ábra: Stratégiai partnerség szereplőinek hálózata}

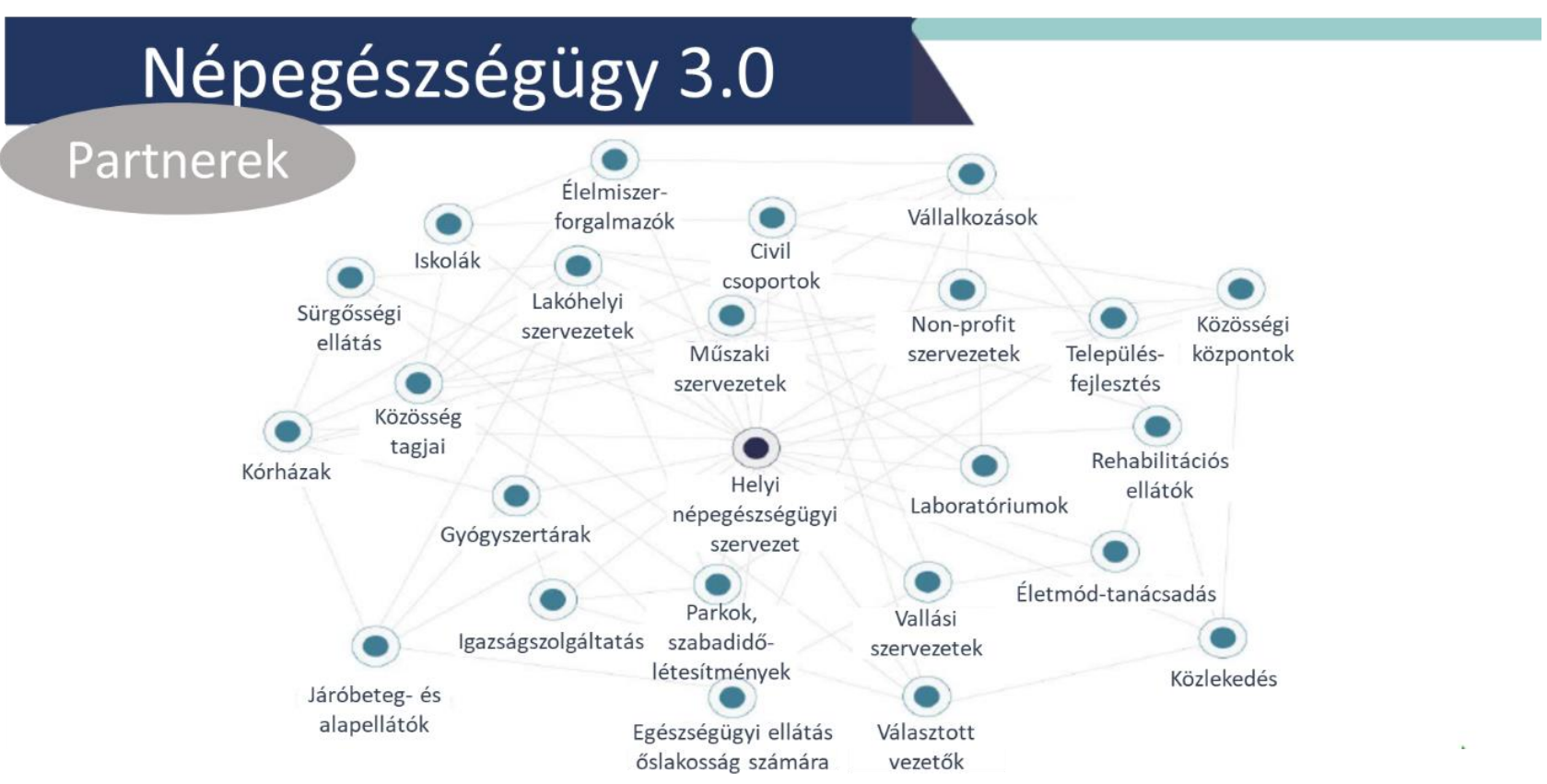

Forrás: az eredeti ábra magyar változata 


\section{TANULSÁGOK HAZAI SZAKEMBEREK SZÁMÁRA}

Azért, hogy áttörést érhessünk el a hazai lakosság egészségi állapotának javításában - azaz az egészségmutatók ranglistáin az utolsó helyekről legalább a középmezőnybe emelkedhessünk -, a helyi népegészségügyi szervezetek Népegészségügy 3.0 stílusú megerősítésére van szükség. Ehhez - felismerve az egyéni életmódváltást erőltető beavatkozások alacsony hatékonyságát -, a hazai népegészségügyben honosítani kellene az egészség társadalmi meghatározóit fókuszba állító rendszerszemléletet. Az ilyen szemléletű képzés, továbbképzés megfelelő tudást, készséget adna a hazai népegészségügyi szakemberek számára az egészséget támogató életkörülmények kialakítását célzó, több ágazat összehangolt cselekvésén alapuló beavatkozások kezdeményezéséhez.

\section{HIVATKOZÁSOK}

${ }^{1}$ Chetty R, Stepner M, Abraham S, et al. The association between income and life expectancy in the United States, 2001-2014. JAMA 2016;315(16):1750-66. doi: 10.1001/jama.2016.4226 